\title{
MEDIACJA JAKO NARZĘDZIE ROZSTRZYGANIA SPORÓW W PRAWIE O WYKROCZENIACH
}

Idea sprawiedliwości naprawczej, opartej na modelu przekazania rozwiązania konfliktu jego stronom, zyskała na znaczeniu w latach siedemdziesiątych XX w. w wyniku nieefektywności koncepcji sprawiedliwości retrybutywnej i resocjalizacyjnej ${ }^{1}$. Podkreślić należy, że ustawodawca w modelu postępowania zmierzającym ku sprawiedliwości naprawczej coraz bardziej zwraca uwagę na rolę pokrzywdzonego i jego wpływ na zakończenie procesu. Generalną ideą sprawiedliwości naprawczej jest naprawienie szkody i/lub zadośćuczynienie krzywdzie wyrządzonej pokrzywdzonemu przez sprawcę czynu zabronionego. I chociaż osoba pokrzywdzona jest w centrum podejmowanych działań, to również sprawca objęty jest odpowiednim wsparciem² ${ }^{2}$ Instrumentem najlepiej urzeczywistniającym powyższą ideę jest mediacja, która do polskiego prawa karnego została bezpośrednio wprowadzona w latach dziewięćdziesiątych jako instrument uzupełniajaccy postępowanie karne, zwłaszcza na etapie postępowania przygotowawczego, oraz postępowanie sądowe na etapie wstępnej kontroli aktu oskarżenia. Zasadnicza zmiana w zakresie mediacji nastapiła wraz z nowelizacją z 10 stycznia 2003 r., po której mediacja zyskała na znaczeniu na wszystkich etapach procesu karnego ${ }^{3}$.

Zauważalne odejście od modelu retrybutywnego na rzecz konsensusu jest wyrazem nowej rzeczywistości prawnej, wyrażającej ogólną tendencję do rozstrzygania spraw karnych $\mathrm{w}$ trybie porozumień procesowych i stosowania uproszczeń proceduralnych w celu odciążenia sądów i oszczędzenia wydatków obciążających wymiar sprawiedliwości ${ }^{4}$. Jednakże nie tylko odciążenie sądów i ekonomika procesowa są wyznacznikiem nowego pojmowania celów procesu. Ustawodawca w coraz większym stopniu podkreśla funkcję restytucyjną procesu, przejawiającą się w dostrzeżeniu ochrony pokrzywdzonego i możliwości zadośćuczynienia mu w procesie karnym.

${ }^{1}$ M. Chalimoniuk-Zięba, G. Oklejak, Sprawiedliwość naprawcza i jej zastosowanie w praktyce, „ADR. Arbitraż i Mediacja” 2013, nr 1, s. 5.

${ }^{2}$ M. Grudziecka, J. Książek, Mediacja jako instytucja dla osoby pokrzywdzonej, w: Międzynarodowa Konferencja „Mediacja w sprawach karnych jako instytucja dla pokrzywdzonego”, Warszawa 7-8 grudnia 2009 r., Warszawa 2010, s. 17.

${ }^{3}$ G.A. Skrobotowicz, Gwarancje praw pokrzywdzonego realizowane w ramach postepowania mediacyjnego a modele postępowań szczególnych, w: D. Gil (red.), Gwarancje praw pokrzywdzonych w postępowaniach szczególnych, Warszawa 2012, s. 212-213.

${ }_{4}^{4}$ Tak: M. Rogacka-Rzewnicka, Dobrowolne poddanie się karze $w$ kodeksie postępowania karnego, Białystok 2002, s. 239-240. 
Analiza celów postępowania jednoznacznie wskazuje na rozważanie sprawy tak, aby pokrzywdzony przestępstwem lub wykroczeniem nie stał się ofiara wiktymizacji wtórnej ${ }^{5}$ i przede wszystkim, aby miał poczucie, że jego prawnie chronione dobra są zabezpieczone i zmniejszone zostało poczucie jego pokrzywdzenia. Jak wskazuje Nils Christie, przestępstwo winno stać się punktem wyjścia prawdziwego dialogu, a nie równie niezdarnej odpowiedzi udzielonej w postaci miarki cierpienia. Systemy społeczne muszą być zbudowane tak, aby dialog był możliwy ${ }^{6}$. Należy zatem w szeroko pojętym systemie prawa karnego poszukiwać rozwiązań alternatywnych wobec kar, opartych na sprawiedliwości naprawczej. Jak podkreśla Ewa Bieńkowska, inkorporowanie programów sprawiedliwości naprawczej do systemów prawa karnego oznacza, że ukradziony stronom przez państwo konflikt karny zostanie im, przynajmniej po części, zwrócony ${ }^{7}$.

W sprawach o wykroczenia jednak podstawy do stosowania mediacji pojawiły się dopiero wraz z ustawą z 27 września 2013 r. o zmianie ustawy Kodeks postępowania karnego oraz niektórych innych ustaw ${ }^{8}$, na mocy której zmieniono treść art. 8 k.p.w. i wskazano, że do postępowania w sprawach o wykroczenia stosuje się art. 23a k.p.k. normujacy instytucję mediacji. Niemniej jednak rola mediacji w postępowaniu w sprawach o wykroczenia jest marginalna i należałoby nadać jej większe znaczenie, zwłaszcza w kontekście statusu pokrzywdzonego. Zaznaczyć trzeba, że z regulacji międzynarodowych ${ }^{9}$ dotyczacych mediacji w sprawach karnych wynika, że jest to instytucja przede wszystkim przeznaczona dla pokrzywdzonego ${ }^{10}$. Analogicznie, z uwagi na dobro pokrzywdzonego wykroczeniem, instytucja mediacji wydaje się niedoceniana w trakcie postępowania w sprawach o wykroczenia. Przy czym trzeba zwrócić uwagę, że w mediacji nie ma mowy o oskarżycielu, ale o pokrzywdzonym, zatem przysługuje mu prawo do mediacji pod warunkiem, że nie wstapił on w rolę oskarżyciela. Na mocy art. $26 \S 3$ ustawy z 24 sierpnia 2001 r. -

5 E. Bieńkowska wskazuje, że przez pojęcie wiktymizacji wtórnej należy rozumieć dodatkowe stresy i traumy odczuwane przez ofiary wskutek przejawiania wobec nich niewłaściwych postaw przez otoczenie społeczne, a zwłaszcza przez agendy szeroko pojętego wymiaru sprawiedliwości karnej (eadem, Mediacja w sprawach karnych, Warszawa 2009, s. 3). Pojęcie to należy odróżnić od wiktymizacji pierwotnej, która obejmuje bezpośrednie, płynące wyłącznie z przestępstwa jego negatywne następstwa psychofizyczne i materialne dla ofiary, takie jak śmierć, uszkodzenia ciała czy cierpienia psychiczne i fizyczne, tak: eadem, Zjawisko wiktymizacji wtórnej. Pojęcie, przyczyny, przeciwdziałanie (na przykładzie niektórych polskich regulacji karnych), „Archiwum Kryminologii” 29-30, 2007-2008, s. 67.

${ }^{6}$ N. Christie, Granice cierpienia, Warszawa 1991, s. 14.

7 E. Bieńkowska, Wiktymizacja wtórna - niepożadany dodatkowy skutek przestepstwa, w: M. Tabernacka, R. Raszewska-Skałecka (red.), Mediacje w społeczeństwie otwartym, Wrocław 2012, s. 97.

8 Dz. U. 2013, poz. 395 ze zm.

9 Zob. rekomendacja Komitetu Ministrów Rady Europy nr R(99)19 o mediacji w sprawach karnych z 15 września 1999 r. oraz dyrektywa Parlamentu Europejskiego i Rady 2012/29/UE z 25 października 2012 r., ustanawiająca normy minimalne w zakresie praw, wsparcia i ochrony ofiar przestępstw oraz zastępująca decyzję ramową Rady 2001/220/WSiSW.

${ }^{10}$ L. Mazowiecka, Szanse na mediacje $w$ postepowaniu przygotowawczym, „Prokuratura i Prawo" 2015, nr 10, s. 92. 
Kodeks postępowania w sprawach o wykroczenia ${ }^{11}$ uprawnienie do działania w charakterze oskarżyciela posiłkowego obok oskarżyciela publicznego wygasa bowiem w terminie 7 dni od zawiadomienia.

Ustawodawca nie wprowadził jednak definicji legalnej mediacji, pozostawiając to doktrynie. Agnieszka Rękas wskazuje, że mediacja to dobrowolne porozumienie między pokrzywdzonym i sprawcą w celu naprawienia wyrządzonych szkód materialnych i moralnych przy pomocy bezstronnej i neutralnej osoby, jaką jest mediator ${ }^{12}$. Ewa Bieńkowska interpretuje mediację jako próbę doprowadzenia do ugodowego, satysfakcjonujacego obie strony rozwiązania konfliktu karnego na drodze dobrowolnych negocjacji prowadzonych przy udziale osoby trzeciej, neutralnej wobec stron i ich konfliktu, czyli mediatora, który wspiera przebieg negocjacji, łagodzi powstające napięcia i pomaga - nie narzucając jednak żadnego rozwiąania - w wypracowaniu porozumienia ${ }^{13}$. Władysław Kopaliński, wyjaśniając termin „mediacja”, wskazuje, że jest to jedna z form rozwiązywania sporów, w ramach której osoba trzecia - mediator, neutralna wobec stron i ich konfliktu, asystuje im w czasie konfliktu lub negocjacji, łagodzi powstające napięcia i pomaga osiagnać stronom korzystne porozumienie, które jest wzajemnie akceptowalne i uwzględnia interesy, a także potrzeby obu stron - nie narzucając przy tym swojego stanowiska ${ }^{14}$.

Prawo do mediacji pełni istotną rolę zarówno pośród praw przysługujących pokrzywdzonemu, jak i sprawcy czynu zabronionego, gdyż nie narusza ono prerogatyw żadnej ze stron, co jest związane z gwarancjami i zasadami postępowania mediacyjnego ${ }^{15}$. Jak wskazuje Justyna Żylińska, za punkt wyjścia przyjać należy występujący pomiędzy podejrzanym o popełnienie wykroczenia/obwinionym a pokrzywdzonym konflikt karny, którego rozwiąanie odbywa się w drodze odformalizowanych negocjacji, w odformalizowanej atmosferze, przy jednoczesnym zaangażowaniu obu podmiotów. Za składowy element definicji dotyczacy uczestniczenia w mediacji uznać należy także mediatora - podmiot, który wspiera przebieg negocjacji i stwarza uczestniczącym w mediacji stronom płaszczyznę do swobodnej, rzeczowej rozmowy, pozostając przy tym osobą neutralną i bezstronną ${ }^{16}$.

Niezrozumienie mediacji wynika przede wszystkim z niewłaściwego pojmowania znaczenia restytucji dla procesu karnego i braku umiejętności przekonywania stron co do jej zasadności. To przecież strony postępowania musza być przekonane o tym, że osiagna pozytywne skutki z mediacji. Zrozumiałe jest $\mathrm{z}$ jednej strony, że organy prowadzące postępowanie chca jak najszybciej je zakończyć, a mediacja to opóźnia. I chociaż art. 23 a $§ 2$ k.p.k. wskazuje

11 T.jedn.: Dz. U. 2016, poz. 1713 ze zm. (dalej jako: k.p.w.).

12 A. Rękas, Mediacja w polskim prawie karnym, Warszawa 2011, s. 3.

${ }^{13}$ E. Bieńkowska, Mediacja $w$ sprawach karnych, Warszawa 2011, s. 4.

${ }_{14}$ W. Kopaliński, Stownik wyrazów obcych $i$ zwrotów obcojęzycznych z almanachem, Warszawa 2000 , s. 321.

${ }^{15}$ G.A. Skrobotowicz, op. cit., s. 215.

${ }_{16}$ J. Żylińska, Mediacja - nowa instytucja w sprawach o wykroczenia, w: I. Nowicka, A. Sadło-Nowak (red.), Wspótczesne problemy wykroczeń. Materialnoprawna i procesowa problematyka wykroczeń, Szczytno 2016, s. 182. 
wprost, że czasu trwania postępowania mediacyjnego nie wlicza się do czasu postępowania karnego, to jednak w praktyce je wydłuża, dlatego té̇ ważne jest wyważenie w procedowaniu, jaki cel chcemy osiagnaćć. Warto zwrócić uwagę, że pozytywnie zakończona mediacja może w konsekwencji skrócić postępowanie dowodowe. Instrument ten, jako alternatywny sposób rozwiązywania sporów, ma wiele zalet, podobnie jak tryby konsensualne, pozwala w większej mierze na uwzględnienie interesów podmiotów bezpośrednio zainteresowanych ostatecznym wynikiem sprawy ${ }^{17}$, a co za tym idzie - może przyspieszyć proces oraz bez wątpienia wpłynąc na większą akceptowalność orzeczeń sądów przez strony. Sąd bądź organ przeprowadzający czynności wyjaśniające akceptuje bowiem i zatwierdza decyzje podejmowane w rzeczywistości przez strony, oczywiście przy spełnieniu ustawowych warunków w tym zakresie. Stworzone zostają także dodatkowe możliwości osiagnięcia porozumienia między sprawca wykroczenia a pokrzywdzonym odnośnie do naprawienia szkody wyrządzonej czynem zabronionym, zatem w pełni realizowana jest funkcja kompensacyjna procesu karnego, a co za tym idzie - zniwelowane zostaja skutki wiktymizacji wtórnej ${ }^{18}$.

Zgodnie z art. $25 \S 1$ k.p.w. przez pojęcie pokrzywdzonego rozumie się tego, czyje dobro prawne zostało bezpośrednio naruszone lub zagrożone przez wykroczenie. Brak tu analogii do unormowania art. 49 § 1 i 2 ustawy z 6 czerwca 1997 r. - Kodeks postępowania karnego ${ }^{19}$, gdzie pokrzywdzony definiowany jest jako osoba fizyczna lub prawna, której dobro prawne zostało bezpośrednio naruszone lub zagrożone przez przestępstwo (§ 1). Pokrzywdzonym może być także nieposiadająca osobowości prawnej: 1) instytucja państwowa lub samorządowa; 2) inna jednostka organizacyjna, której odrębne przepisy przyznają zdolność prawna (§ 2). A ponadto za pokrzywdzonego uważa się zakład ubezpieczeń w zakresie, w jakim pokrył szkodę wyrządzona pokrzywdzonemu przez przestępstwo lub jest zobowiązany do jej pokrycia, co oznacza, że nie jest on uważany za pokrzywdzonego, ale przysługują mu uprawnienia pokrzywdzonego. Uznać jednak należy, że przyjęcie przez ustawodawcę bardziej ogólnego określenia pokrzywdzonego w sprawach o wykroczenia, wskazuje z założenia na każdy podmiot, którego dobro zostało bezpośrednio przez wykroczenie naruszone lub zagrożone. Zarówno w przypadku pokrzywdzonego wykroczeniem, jak i pokrzywdzonego przestępstwem istotna jest bezpośredniość naruszenia lub zagrożenia jego dobra prawnego, co oznacza, że pomiędzy naruszeniem lub zagrożeniem dobra prawnego a czynem nie może być żadnych pośrednich ogniw. Zatem pośrednie naruszenie czyjegoś dobra prawnego nie czyni go pokrzywdzonym. Potwierdza to również Sąd Najwyższy, uznajacc, że o pokrzywdzeniu decyduje bezpośredniość naruszonego lub

17 K. Urbanowicz, Formy konsensualizmu procesowego w świetle ostatnich nowelizacji Kodeksu postepowania karnego, „Zeszyt Studencki Kół Naukowych Wydziału Prawa i Administracji UAM" 2016, nr 2, s. 270.

18 Tak: W. Jasiński, Porozumienia procesowe w znowelizowanym kodeksie postepowania karnego, „Prokuratura i Prawo” 2014, nr 10, s. 6; S. Steinborn, Porozumienia w polskim procesie karnym: skazanie bez rozprawy i dobrowolne poddanie się odpowiedzialności karnej, Kraków 2005, s. 42 .

19 T.jedn.: Dz. U. 2016, poz. 1749 ze zm. (dalej jako: k.p.k.). 
zagrożonego przestępstwem dobra ${ }^{20}$. W procedurze karnej ustawodawca jednak przewiduje dwa wyjątki od zachowania wymogu bezpośredniości, które dotycza zakładu ubezpieczeń społecznych (art. 49 § 3 k.p.k.) oraz Państwowej Inspekcji Pracy (art. $49 \S 3$ a k.p.k.) ${ }^{21}$. Recypowanie art. $49 \S 3$ k.p.k. (art. $25 \S 3$ k.p.w. in principio) wskazuje, że zakład ubezpieczeń społecznych również uznawany jest za pokrzywdzonego w ramach procedury wykroczeniowej w zakresie, w jakim pokrył szkodę wyrządzoną pokrzywdzonemu lub jest zobowiązany do jej pokrycia. $\mathrm{Na}$ marginesie dodać należy, że inaczej jest w przypadku poszkodowanego na gruncie prawa cywilnego, gdzie owa bezpośredniość nie jest wymagana ${ }^{22}$.

Cel postępowania w sprawach o wykroczenia został przez ustawodawcę precyzyjnie określony w art. $2 \S 1$ k.p.k., który przez przepis art. 8 k.p.w. ma zastosowanie $\mathrm{w}$ tym postępowaniu. Zgodnie $\mathrm{z}$ powyższym przepisem per analogiam sprawca czynu zabronionego jako wykroczenie ma zostać wykryty i pociagnięty do odpowiedzialności. Przez trafne zastosowanie środków przewidzianych prawem oraz ujawnienie okoliczności sprzyjających popełnieniu wykroczenia osiagnięte winny zostać zadania postępowania nie tylko $\mathrm{w}$ zwalczaniu wykroczeń, lecz także $\mathrm{w}$ zapobieganiu im oraz $\mathrm{w}$ umacnianiu poszanowania prawa i zasad współżycia społecznego. Rozstrzygnięcie sprawy powinno nastapić $\mathrm{w}$ rozsądnym terminie. Ustawodawca, tak jak i w postępowaniu karnym, podkreśla już na samym początku, że celem postępowania $\mathrm{w}$ sprawach o wykroczenia jest także uwzględnienie prawnie chronionych interesów pokrzywdzonego. Wynikające z nowelizacji przepisów karnych poszerzenie uprawnień pokrzywdzonego należy przyjać z aprobata, gdyż wymóg uwzględniania prawnie chronionych interesów pokrzywdzonego wraz z poszanowaniem jego godności powinien być urzeczywistniony jako cel postępowania karnego (a także wykroczeniowego), wynikający z art. $2 \S 1$ pkt 1 k.p.k. ${ }^{23}$

Prawidłowe i skuteczne realizowanie celów postępowania w sprawach o wykroczenia dążyć powinno do rozwiązania konfliktu, którym jest wykroczenie, a nie jedynie do wymierzenia sprawcy kary określonego rodzaju za popełniony czyn. Dotychczasowa, zdominowana przez interes państwa polityka karania, która sprowadzała się w istocie do ukarania sprawcy, a także niedoceniania restytucji i kompensacji oraz pomijania ważnej roli rozwiazywania konfliktu społecznego, jaki powstał pomiędzy sprawca a pokrzywdzonym wskutek popełnienia czynu zabronionego, zmienia się ${ }^{24}$. O ile $\mathrm{w}$ prawie karnym od dawna zwraca się uwagę na znaczenie funkcji restytucyjnej ${ }^{25}$, o tyle

${ }^{20}$ Postanowienie SN z 17 listopada 2005 r., II KK 108/05, OSNwSK 2005, poz. 2094.

${ }^{21}$ K. Eichstaedt, w: D. Świecki (red.), Kodeks postepowania karnego. Komentarz, t. 1, Warszawa 2013, s. 277.

22 T. Grzegorczyk, Kodeks postepowania w sprawach o wykroczenia. Komentarz, Warszawa 2012, s. 118-119.

${ }_{23}$ D. Drajewicz, Pokrzywdzony w znowelizowanym Kodeksie postepowania karnego, „Monitor Prawniczy" 2015, nr 18, s. 970.

${ }_{24}$ Uzasadnienie rzadowego projektu kodeksu karnego, w: Nowe kodeksy karne z 1997 r. z uzasadnieniem, Warszawa 1997, s. 146.

25 Należy zauważyć, że mediacja do postępowania karnego została wprowadzona już w 1997 r., początkowo jako regulacja art. 320 k.p.k., następnie w 2003 włączona do części materialnej prawa karnego statuowana w art. 23a k.k. 
w prawie wykroczeń znaczenie restytucji było przez wiele lat przez ustawodawcę jakby niezauważane, a przecież cele postępowania są tożsame dla obu postępowań. Zmiana nastapiła dopiero w 2013 r., kiedy ustawą z 27 września 2013 r. o zmianie ustawy - Kodeks postępowania karnego oraz niektórych innych ustaw (ogłoszona 25 października 2013, weszła w życie dopiero 1 lipca 2015 r.) wprowadzono nowe brzmienie art. 8 k.p.w., przez co włączono do postępowania w sprawach o wykroczenia instytucję mediacji występujacca na gruncie art. 23a k.p.k. Na mocy tego przepisu sąd lub referendarz sądowy (a per analogiam w toku czynności wyjaśniajaccych - organ prowadzaccy to postępowanie) może z inicjatywy lub za zgodą pokrzywdzonego i oskarżonego skierować sprawę do instytucji lub osoby do tego uprawnionej w celu przeprowadzenia postępowania mediacyjnego między pokrzywdzonym i oskarżonym, o czym się ich poucza, informując o celach i zasadach postępowania mediacyjnego, a w tym o treści art. 178a k.p.k. ${ }^{26}$ Należy dodać, że ustawodawca w nowelizacji art. $23 a \S 1$ k.p.k. odszedł od dotychczasowego nazywania mediatora „osoba godną zaufania” i wprowadził nazwę „osoba do tego uprawniona".

Tryb przeprowadzenia mediacji w postępowaniu w sprawach o wykroczenia, poza wskazanym art. 23a k.p.k. w zw. z art. 8 k.p.w., został określony przez ustawodawcę w rozporządzeniu Ministra Sprawiedliwości z 7 maja 2015 r. w sprawie postępowania mediacyjnego w sprawach karnych ${ }^{27}$, które weszło w życie 1 lipca 2015 r. Rozporządzenie to określa m.in.: szczegółowy tryb przeprowadzania postępowania mediacyjnego; warunki, którym powinny odpowiadać instytucje i osoby uprawnione do przeprowadzenia postępowania mediacyjnego oraz sposób powoływania i odwoływania instytucji i osób uprawnionych do przeprowadzenia postępowania mediacyjnego. Natomiast przeprowadzenie postępowania mediacyjnego może zostać powierzone tzw. instytucji uprawnionej, tj. instytucji, która: zgodnie ze swoimi zadaniami statutowymi została powołana do wykonywania zadań w zakresie mediacji, resocjalizacji, ochrony interesu społecznego, ochrony ważnego interesu indywidualnego lub ochrony wolności i praw człowieka; zapewnia przeprowadzenie postępowania mediacyjnego przez osoby spełniające warunki, o których mowa poniżej; posiada warunki organizacyjne umożliwiajace przeprowadzenie postępowania mediacyjnego; a także została wpisana do wykazu.

Sama osoba mediatora musi spełniać także ściśle określone warunki. Zgodnie z $§ 4$ rozporządzenia do przeprowadzenia postępowania mediacyjnego jest uprawniona osoba, która: spełnia wymóg posiadanego obywatelstwa ${ }^{28}$; ko-

${ }^{26}$ Ustawowy zakaz przesłuchania mediatora co do faktów, o których dowiedział się od stron w trakcie prowadzenia postępowania mediacyjnego, został wprowadzony ustawą z 27 września 2013 r. o zmianie ustawy - Kodeks postępowania karnego oraz niektórych innych ustaw, do wejścia w życie tej ustawy, mediator nie miał prawa do odmowy złożenia takich zeznań, co było sprzeczne z założeniem mediacji, a w szczególności jej poufnościa. Dopiero wprowadzenie wskazanego zakazu pozwoliło na realizację zasady poufności postępowania mediacyjnego.

${ }^{27}$ Dz. U. 2015, poz. 716.

${ }^{28} \mathrm{Tj}$. osoba, która posiada obywatelstwo polskie, obywatelstwo innego państwa członkowskiego Unii Europejskiej, państwa członkowskiego Europejskiego Porozumienia o Wolnym Handlu (EFTA) - strony umowy o Europejskim Obszarze Gospodarczym lub Konfederacji Szwajcar- 
rzysta w pełni z praw publicznych i ma pełną zdolność do czynności prawnych; ukończyła 26 lat; zna język polski w mowie i piśmie; nie była prawomocnie skazana za umyślne przestępstwo lub umyślne przestępstwo skarbowe; posiada umiejętności i wiedzę w zakresie przeprowadzania postępowania mediacyjnego, rozwiązywania konfliktów i nawiązywania kontaktów międzyludzkich; daje rękojmię należytego wykonywania obowiązków; a także została wpisana do wykazu prowadzonego w sądzie okręgowym.

W cytowanym rozporządzeniu przewidziano ponadto możliwość powołania w konkretnej sprawie i w wyjątkowych przypadkach (uzasadnionych potrzebą skutecznego przeprowadzenia postępowania mediacyjnego) instytucji albo osoby spoza wykazu zgłaszającej taką gotowość, jeżeli spełnia ona określone warunki. Spełnienie wskazanych powyżej warunków jest zatem niezbędne do uzyskania przymiotu instytucji bądź osoby uprawnionej.

Należy pamiętać, że to strony postępowania muszą wyrazić chęć skorzystania z mediacji, natomiast rolą organu jest jedynie wprowadzenie ich do mediacji. Jedna z zasadniczych cech tego instrumentu jest przecież dobrowolność. Mediacja może odbyć się tylko wówczas, gdy obie strony postępowania - sprawca wykroczenia i pokrzywdzony wyrażą wolę jej przeprowadzenia. Jeżeli w czasie postępowania tylko jedna ze stron postępowania wyrazi chęć skorzystania z mediacji, druga zaś będzie jej przeciwna, organ prowadzacy postępowanie nie będzie mógł skierować sprawy do mediacji. Mediacja może bowiem odnieść swój skutek wyłącznie w przypadku nieprzymuszonej, swobodnej i nieskrępowanej niczym woli stron do skorzystania z tego narzędzia służącego konsensualnemu rozwiązaniu konfliktu ${ }^{29}$. Uczestniczenie w postępowaniu mediacyjnym powinno zatem stanowić konsekwencję świadomej decyzji podjętej przez uczestniczace w niej strony, a wymóg zainicjowania postępowania stanowić winna nieprzymuszona wola oraz gotowość do wypełnienia przyszłych, przyjętych w ramach mediacji zobowiąań ${ }^{30}$.

Nierozerwalnie z mediacją związana jest zasada poufności, która dopiero wraz ze zmianą przepisu art. 23a k.p.k. w 2013 r. doczekała się pełnej realizacji. Wszystko to, o czym rozmawiaja strony $\mathrm{w}$ toku postępowania mediacyjnego, ma charakter poufny. Poufność dotyczy przede wszystkim mediatora sporządzającego sprawozdanie z mediacji. Same strony oraz inni uczestnicy mediacji (np. profesjonalni pełnomocnicy czy przedstawiciele ustawowi) także nie powinni upubliczniać żadnych treści oraz faktów, które zaszły podczas mediacji ${ }^{31}$. Mediatora np. nie można obecnie przesłuchiwać, co faktów, o których dowiedział się w trakcie trwania postępowania mediacyjnego (art. 178a k.p.k., który ma również zastosowanie w postępowaniu w sprawach o wykroczenia). Taki zapis daje stronom gwarancję, że okoliczności, o których strony zdecydo-

skiej albo obywatelstwo innego państwa, jeżeli na podstawie przepisów prawa Unii Europejskiej przysługuje jej prawo podjęcia zatrudnienia lub samozatrudnienia na terytorium Rzeczypospolitej Polskiej na zasadach określonych w tych przepisach.

${ }^{29}$ G. Skrobotowicz, Zalety mediacji karnej, „Prokuratura i Prawo” 2012, nr 2, s. 132.

30 Tak: K. Liżyńska, J. Żylińska, Prawne i psychologiczne skutki mediacji w sprawach karnych, w: M. Tabernacka, R. Raszewska-Skałecka (red.), Mediacje..., s. 149.

31 G. Skrobotowicz, Zalety mediacji..., s. 133-134. 
wały się opowiedzieć w trakcie mediacji i w obecności mediatora, nie zostana ujawnione przed organami ścigania czy sądem.

Uczestniczące w mediacji strony, winny być traktowane jednakowo, maja one przecież te same prawa i obowiązi. Mediator zatem nie powinien być zaangażowany w spór pomiędzy stronami na tyle, by opowiadać się za interesami którejśs z nich, ma on jedynie prowadzić mediację, a nie w niej uczestniczyć. Jest to wyrazem bezstronności postępowania mediacyjnego. Mediator ma za zadanie wspierać przebieg negocjacji, pomagać stronom w pełnym uczestniczeniu i osiaganiu korzyści z mediacji, nie faworyzując jednak żadnej z nich, w szczególności pokrzywdzonego ${ }^{32}$. Mediator nie jest pełnomocnikiem ani obrońcą uczestniczących w mediacji stron. Nie wolno mu także zajmować stanowiska w zakresie określenia winy sprawcy wykroczenia. Bezstronności służyć ma także wyłączenie kategorii osób, które nie mogą prowadzić postępowania mediacyjnego. Sa to: osoby wykazujace powiązania z uczestnikami postępowania, a także te, za których wyłączeniem przemawiają szczególne okoliczności (art. 40-42 k.p.k.), oraz osoby, które ze względu na pełnioną funkcję lub miejsce, w którym są zatrudnione, nie powinny łączyć aktywności zawodowej z funkcją mediatora - sędzia, prokurator, asesor prokuratorski, a także aplikanci do tychże zawodów, ławnik, referendarz sądowy, asystent sędziego, asystent prokuratora oraz funkcjonariusz instytucji uprawnionej do ścigania przestępstw $^{33}$. Nie ma jednak przeszkód, by mediację prowadziły inne osoby, niewymienione tu, a zatrudnione w sądzie, prokuraturze czy instytucji uprawnionej do ścigania przestępstw.

Mediacji towarzyszy także zasada neutralności, zgodnie z którą mediator nie narzuca stronom postępowania własnych rozwiązań, nawet gdy według jego wiedzy będą one bardziej dla stron korzystne, umiejętnie prowadzi jedynie negocjacje, których decyzje końcowe należą do stron, a nie do mediatora. Rola mediatora sprowadza się do wspierania przebiegu negocjacji - stworzenia uczestniczaccym w mediacji stronom płaszczyzny do spokojnej, rzeczowej rozmowy oraz udzielenia pomocy w wypracowaniu rozwiązania, które będzie odpowiadać ich interesom czy potrzebom ${ }^{34}$.

Cel mediacji, którym jest doprowadzenie do porozumienia pomiędzy stronami, zostanie zrealizowany, gdy reguły mediacji i osoba mediatora sa przez strony akceptowane. Jeżeli wystapi brak akceptowalności przez którąkolwiek ze stron zasad, ustaleń, bądź samej osoby mediatora, może dojść nawet do zaostrzenia konfliktu pomiędzy stronami, a sama mediacja okaże się niepotrzebnym instrumentem przedłużajacym w tej sytuacji samo postępowanie. Podkreślić należy, że celem mediacji jest wypracowanie porozumienia, które zostanie przyjęte przez obie strony. Kwintesencję całego procesu mediacyjnego stanowi wypracowanie stanowiska, w którym zarówno pokrzywdzony, jak i sprawca będą się czuli „wygranymi”. Skoro strony dobrowolnie i automatycz-

32 Tak: K. Liżyńska, J. Żylińska, op. cit., s. 150.

${ }^{33}$ Tak: P. Hofmański, E. Sadzik, K. Zgryzek, Kodeks postepowania karnego. Komentarz, t. 1, Warszawa 2013, s. 241. Wynika to wprost z regulacji art. 3 k.p.k. oraz rozporządzenia Ministra Sprawiedliwości z 7 maja 2015r. w sprawie postępowania mediacyjnego w sprawach karnych.

34 J. Żylińska, op. cit., s. 184. 
nie przyjęły określone deklaracje, to są w stanie je wypełnić ${ }^{35}$. Akceptowalność zatem to kolejna niezbędna cecha optymalnego procesu mediacji. Dodać trzeba, że strony mają prawo do zmiany osoby mediatora, jeżeli - ich zdaniem - nie spełnia on warunku, np. bezstronności. Mediator ma prawo także zrezygnować z mediacji ${ }^{36}$.

Reasumując, instytucja mediacji powstała z potrzeby praktyki zadośćuczynienia za wyrządzoną szkodę czy doznaną krzywdę oraz z nowego spojrzenia na filozofię odpowiedzialności karnej. Daje ona stronom większą autonomię $\mathrm{w}$ zakresie rozporządzania swoimi prawami oraz zawiera $\mathrm{w}$ sobie restytucję jako przejaw pogodzenia sprawcy z ofiara ${ }^{37}$. W mediacji odchodzi się od tradycyjnego wymierzania sprawiedliwości przez sądy na rzecz sprawiedliwości indywidualnej, co wymaga zmiany świadomości i zmiany nastawienia w podejściu do sporów. Jednak dopiero zrozumienie zakresu mediacji, a przede wszystkim jej skutków zarówno w zakresie prawnym, jak i moralnym przez strony, przyniesie zysk zarówno sprawcy wykroczenia, jak i pokrzywdzonemu. Dlatego też optować należy za tym, iż to na organach prowadzących czy to czynności wyjaśniające, czy też postępowanie przed sądem spoczywać winien ciężar umiejętnego wytłumaczenia, czym jest mediacja i zapoznanie stron z możliwościami zakończenia sporu przez mediację. Ważne jest odpowiednie szkolenie osób prowadzacych te postępowania z zakresu psychologii, by właściwie przedstawić stronom tę instytucję. Zresztą wymóg pouczenia przez organ procesowy stron postępowania o zasadach i celach mediacji wynika wprost z art. 23a k.p.k. Obowiązek ten jest także wyrazem realizacji dyspozycji zawartych w Rekomendacji Komitetu Ministrów Rady Europy nr (99) 19.

Nieumiejętne przedstawienie stronom instytucji mediacji doprowadzić może do niemożności wykorzystania tego alternatywnego rozpoznania sporu. Słusznie wskazuje E. Bieńkowska, że cały czas mamy do czynienia z niezrozumieniem istoty i znaczenia łagodzenia zarówno bezpośrednich, jak i dalszych skutków przestępstw (co jest właściwe także wykroczeniom) nie tylko dla ofiar przestępstw i ich rodzin, ale również dla społeczności lokalnych, w których osoby te funkcjonuja. Nie jest także doceniana waga takich przedsięwzięć w procesie przywracania zaufania w stosunkach społecznych i w odniesieniu do oficjalnych instytucji państwa, a w tym przede wszystkim - do policji i agend wymiaru sprawiedliwości ${ }^{38}$. Dlatego ważne jest z jednej strony właściwe pojmowanie mediacji przez osoby prowadzące postępowanie, a z drugiej - umiejętne przedstawienie charakteru tej instytucji stro-

${ }^{35}$ G. Skrobotowicz, Zalety mediacji..., s. 131.

${ }^{36}$ Tak: K. Liżyńska, J. Żylińska, op. cit., s. 150. Por. też: A. Rękas, op. cit., s. 4-5; A. Tombek-Knigawska, W. Kotowski, Dlaczego kieruję sprawy do postępowania mediacyjnego?, „Prokuratura i Prawo" 2011, nr 3, s. 122-123; A. Rękas, Mediacja w polskim prawie karnym - uregulowania prawne i praktyka, w: S.L. Stadniczeńko (red.), Prawno-psychologiczne uwarunkowania mediacji $i$ negocjacji, Opole 2006, s. 139 i n.; A. Zienkiewicz, Przeglad założeń najpopularniejszych strategii mediacyjnych, w: idem (red.), Studium mediacji. Od teorii ku praktyce, Warszawa 2007, s. $170-207$.

${ }^{37}$ A. Rękas, Mediacja w polskim..., s. 3.

${ }^{38}$ E. Bieńkowska, Wiktymizacja wtórna..., s. 103. 
nom. Strony winny uzyskać wyczerpujące informacje o przysługujących im prawach, zasadach mediacji i możliwości odstapienia od mediacji w każdym czasie jej trwania.

Analiza instytucji mediacji jako alternatywnego sposobu rozwiązywania sporu pomiędzy pokrzywdzonym a sprawca czynu zabronionego wymaga również wskazania, że sama mediacja nie jest pozbawiona wad. Na gruncie prawa karnego Grzegorz A. Skrobutowicz zauważa brak równowagi w sferze ochrony interesów stron konfliktu, a wręcz jednoznaczne jej skierowanie $\mathrm{w}$ stronę sprawcy, podnosząc chociażby to, że na gruncie art. $53 \S 3 \mathrm{k} . \mathrm{k}$. pozytywne wyniki przeprowadzonej mediacji albo ugoda zawarta pomiędzy pokrzywdzonym a sprawcą sa brane pod uwagę przez sąd podczas wymierzania kary, podczas gdy tak naprawdę pokrzywdzony nie ma gwarancji realizacji ustalonych $\mathrm{w}$ drodze ugody ustalen ${ }^{39}$. Odmiennie jest jednak na gruncie prawa o wykroczeniach, gdyż w art. $33 \mathrm{k} . w$. brak jest analogicznego rozwiązania.

Wprowadzenie instytucji mediacji stanowiącej proces rozwiązywania drobnych konfliktów, jakimi są wykroczenia, jest z pewnością rozwiązaniem optymalnym zarówno dla pokrzywdzonego, jak i dla sprawcy czynu zabronionego. Pamiętać jednak należy, że aby takie konsensualne rozwiązanie odniosło swój skutek, musi się opierać na wskazanych powyżej kluczowych zasadach, takich jak: dobrowolność, poufność, bezstronność mediatora oraz akceptowalność ${ }^{40}$. Z punktu widzenia pokrzywdzonego mediacja stwarza mu możliwość poczucia moralnej i psychicznej satysfakcji przy jednoczesnym uniknięciu stresu związanego z wtórną wiktymizacja, wywołanego kontaktem z organami ścigania i wymiarem sprawiedliwości ${ }^{41}$. Pozytywnie należy również ocenić wprowadzony ustawą z 27 września 2013 r. art. 45 § 2a k.w., zgodnie z którym czasu wszczętego postępowania mediacyjnego nie wlicza się do okresu przedawnienia. Innymi słowy, okres przedawnienia przedłuża się o czas między wszczęciem postępowania mediacyjnego a jego zakończeniem, który w zasadzie może trwać maksymalnie miesiąc ${ }^{42}$.

Konkludując, instytucja mediacji w sprawach o wykroczenia jest instytucją stosunkowo młoda. Należy jednak spodziewać się, że z uwagi na specyfikę wykroczeń i ich stopień społecznej szkodliwości, a tym samym znikomy charakter konfliktów leżących u podstaw zachowań sprawców, w przyszłości mediacja jako alternatywny dla postępowania sądowego sposób rozwiązywania sporów zyska na znaczeniu. Mediacja jest bowiem przejawem unowocześnionego spojrzenia na filozofię odpowiedzialności za popełnienie wykroczenia opartego na idei sprawiedliwości naprawczej, powstałym w odpowiedzi na potrzeby praktyki. I o ile z punktu widzenia pokrzywdzonego początkowo może ona budzić sceptyczne nastawienie, o tyle należy podkreślić, że staje się on czynnym uczestnikiem mediacji mającym istotny wpływ na konstruktywne

${ }^{39}$ G.A. Skrobotowicz, Gwarancje praw..., s. 227.

${ }^{40}$ Zob. szerzej: J. Żylińska, op. cit., s. 182 i n.

${ }^{41}$ Ibidem, s. $188-189$.

${ }^{42}$ W. Radecki, w: M. Bojarski, W. Radecki, Kodeks wykroczeń. Komentarz, Warszawa 2013, s. 376 . 
działania mające na celu optymalne zakończenie konfliktu, a przy odpowiednim kształtowaniu świadomości społecznej oraz profesjonalnym podejściu mediatorów instytucja ta przyniesie wymierne korzyści zarówno pokrzywdzonemu, jak i sprawcy, jednocześnie zapewni realizację zasady ekonomiki postępowania w sprawach o wykroczenia.

dr Katarzyna Liżyńska

Uniwersytet Wroctawski

katarzyna.lizynska@uwr.edu.pl

dr Anna Ptońska

Uniwersytet Wroctawski

anna.plonska@uwr.edu.pl

\section{MEDIATION AS AN INSTITUTION FOR THE SETTLEMENT OF DISPUTES UNDER PETTY OFFENCES LAW}

\section{Sum mary}

Mediation as an institution for the settlement of disputes under petty offences law is a relatively new concept. However, given the nature of petty offences and the degree of the social harm they cause, it is gaining in importance as an amicable dispute resolution alternative to court proceedings in which conflicts between the petty offence perpetrator and the victim can be resolved. This article aims at presenting mediation as a modernised approach to the philosophy of responsibility for committing a petty offence, based on the idea of corrective justice from the victim's perspective. 
